\title{
EHMTI-0278. Onabotulinum toxin a for hemicrania continua: a case series of 8 patients
}

\author{
S Miller ${ }^{1 *}$, F Correia ${ }^{2}$, S Lagrata ${ }^{1}$, M Matharu $^{1}$ \\ From 4th European Headache and Migraine Trust International Congress: EHMTIC 2014 \\ Copenhagen, Denmark. 18-21 September 2014
}

\section{Introduction}

Hemicrania Continua $(\mathrm{HC})$ is a strictly unilateral continuous headache that is exquisitely responsive to Indometacin but some patients cannot tolerate this drug. Evidence for other therapies is limited, often limited to single case reports.

\section{Aim}

Onabotulinum Toxin A (BoNT-A) is licensed for use in chronic migraine. Previous case reports on its use in $\mathrm{HC}$ are limited to two patients. We present outcome data on eight patients with $\mathrm{HC}$ treated with BoNT-A.

\section{Methods}

Eight patients with $\mathrm{HC}$ received BoNT-A treatment as per the PRE-EMPT protocol for chronic migraine. Clinical data was collected pre and post-treatment. Headache load (defined as [severity (on the visual analogue score)] $\mathrm{x}$ [duration] $x$ [frequency] of headaches) of each patient was calculated before and after treatment.

\section{Results}

The median number of treatments was 2 (range 1-8) and the median number of BoNT-A units injected 165 (range 134-185). Six patients showed a headache load reduction of over $50 \%$. Median improvement in headache load posttreatment was $88.5 \%(0-100 \%)$ with a significant difference in headache load post-treatment $(\mathrm{p}=0.018)$. The median duration of effect was 9.5 weeks ( $0-20$ weeks). Five of six responders were previously taking Indometacin on a daily basis. All were able to switch to intermittent use of the drug.

\section{Conclusions}

BoNT-A may be a useful treatment for $\mathrm{HC}$ where Indometacin is not tolerated and adds another potential option to the limited therapeutic arsenal currently available.

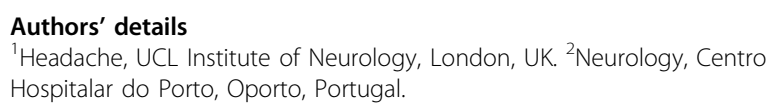

Published: 18 September 2014

doi:10.1186/1129-2377-15-S1-C45

Cite this article as: Miller et al: EHMTI-0278. Onabotulinum toxin a for hemicrania continua: a case series of 8 patients. The Journal of Headache and Pain 2014 15(Suppl 1):C45.
Submit your manuscript to a SpringerOpen ${ }^{\circ}$ journal and benefit from:

- Convenient online submission

- Rigorous peer review

- Immediate publication on acceptance

- Open access: articles freely available online

- High visibility within the field

- Retaining the copyright to your article (c) 2014 Miller et al; licensee Springer. This is an Open Access article distributed under the terms of the Creative Commons Attribution License (http://creativecommons.org/licenses/by/2.0), which permits unrestricted use, distribution, and reproduction in any medium, provided the original work is properly cited. 